\title{
WHAT CAN THE TAKE-UP OF OTHER PROGRAMS TEACH US ABOUT HOW TO IMPROVE TAKE-UP OF HEALTH INSURANCE PROGRAMS?
}

\author{
Dahlia K. Remler \\ Jason E. Rachlin \\ Sherry A. Glied \\ Working Paper 8185 \\ http://www.nber.org/papers/w8185 \\ NATIONAL BUREAU OF ECONOMIC RESEARCH \\ 1050 Massachusetts Avenue \\ Cambridge, MA 02138 \\ March 2001
}

We gratefully acknowledge funding from the Commonwealth Foundation Project on Workable Solutions. The views expressed herein are those of the authors and not necessarily those of the National Bureau of Economic Research.

(C) 2001 by Dahlia K. Remler, Jason E. Rachlin and Sherry A. Glied. All rights reserved. Short sections of text, not to exceed two paragraphs, may be quoted without explicit permission provided that full credit, including (C) notice, is given to the source. 
What can the take-up of other programs teach us about how to improve take-up of health insurance programs?

Dahlia K. Remler, Jason A. Rachlin and Sherry A. Glied

NBER Working Paper No. 8185

March 2001

JEL No. I1

\begin{abstract}
Many uninsured Americans are already eligible for free or low-cost public coverage through Medicaid or CHIP but do not take up that coverage. Several other programs, such as food stamps and unemployment insurance, also have less than complete take-up rates and take-up rates vary considerably among programs. This paper examines the take-up literature across a variety of programs to learn what effects non-financial features, such as administrative complexity, have on take-up. We find that making benefit receipt automatic is the most effective means of ensuring high take-up, while there is little evidence that stigma is important. Overall, surprisingly little is known about the quantitative impact, of non-financial characteristics of programs on take-up. New research that could be used to draw measurable causal inferences about how features as administrative complexity, renewal rules, and organizational structure affect participation, would be extremely valuable.
\end{abstract}

Dahlia K. Remler

Division of Health Policy and Management

Mailman School of Public Health

Columbia University

600 West $168^{\text {th }}$ St., $6^{\text {th }}$ floor

New York, NY 10032

dr404@columbia.edu

Sherry A. Glied

Division of Health Policy and Management

Mailman School of Public Health

Columbia University

600 West $168^{\text {th }}$ St., $6^{\text {th }}$ floor

New York, NY 10032

sag1@,columbia.edu
Jason E. Rachlin

Division of Health Policy and Management

Mailman School of Public Health

Columbia University

600 West $168^{\text {th }}$ St., $6^{\text {th }}$ floor

New York, NY 10032

jer61@,columbia.edu 


\section{Introduction}

A substantial fraction of uninsured Americans are already eligible for public coverage through the Medicaid or CHIP programs (Selden et al 1998). Understanding why they do not take up this coverage is critical to further insurance expansions. Financial costs play an important and well-documented role in determining participation for programs that require payment out of pocket by the participant. Most public programs, however, require no out-of-pocket payments yet still have low participation rates. Other factors must play a significant role in determining participation. Analysts often cite the stigma attached to public programs, the time needed to participate, the difficulty of the forms and process procedures, and lack of information about the availability of such programs as such factors. What little evidence about these other factors effects exists, however, is primarily qualitative and self-reported, based on focus groups (Perry, Stark and Valdez 1998) and reports of officials (GAO 1999). Their quantitative magnitude is entirely unknown.

While the lack of take-up of health insurance is of policy concern today, many other public programs also have low take-up rates. Food stamps, unemployment insurance and Aid to Families with Dependent Children (AFDC, now TANF) all have take-up rates similar to that of Medicaid (Table1). In trying to improve health insurance programs, it is worth seeing what lessons can be learned from the take-up of other programs.

In this paper, we examine the literature of take-up across health care and other programs. Because the impact of direct financial costs is already well documented, we concentrate on all other program features. 
To find take up studies, we conducted searches of Econlit and Social Science Abstracts using the keywords "take-up", "takeup" and "program participation". We also asked colleagues, including those on listservers in the policy field about studies and searched the web sites of various policy research organizations. Most studies were empirical studies of one-- or at most two-- programs. The overwhelming share examine cross-sectional variation in take-up of a particular program and the individual characteristics that predict take-up. A few studies make use of variation in program features over time and one study documents a randomized controlled experiment. Several qualitative studies asked eligibles why they had not participated in programs. We also looked across programs to see what could be learned through the correlation of take-up with program design.

\section{What Factors Might be Expected to Influence Take-up}

Conceptually, we expect eligible people to take up a program if its benefits to them exceed its costs. These costs have been characterized by Craig $(1991)^{1,2}$ as information costs (the difficulty or complexity of the tasks needed to become enrolled, reporting requirements, and lack of knowledge), process costs (out of pocket costs, time required to become enrolled) and outcome costs ("stigma") ${ }^{3}$.

Benefits depend on the value the program provides to the recipient. Even for cash programs, where benefits would appear obvious, the value to the potential recipient still

\footnotetext{
${ }^{1}$ A similar list appears in Dion and Pavetti (2000) as the possible factors influencing take-up of Food stamps and Medicaid.

${ }^{2}$ Craig has a useful review of the literature on take-up of cash assistance programs, in many countries but particularly in Britain. He reviews both psychological and economic models of take-up and research by social researchers and economists. He finds despite a significant body of work, the literature is "scattered and patchy" and that work with samples of eligible non-recipients is critical.
} 
depends on the size of the benefit relative to their general level of wealth and income and the opportunities foregone through participation (such as work income for welfare programs). For programs such as education or housing vouchers, assessing the value of benefits is even more complicated since tastes for education and housing clearly vary. For health insurance, benefits depend on the potential recipient's health status, belief in the usefulness of healthcare, attitudes toward financial risk, and access to alternative sources of medical care (such as public hospitals). We will characterize the possible influences of take-up (other than financial cost) as: program benefits, inconvenience, cultural attitudes and stigma, and information.

While common sense and anecdote are the main sources of information about barriers to take-up, there is some qualitative evidence. For example, focus groups described the barriers to take-up of Medicaid (Perry, Stark and Valdez 1998). They find that changing eligibility status over time, confusion over eligibility, language barriers, fears about immigration and residency, an onerous enrollment process, and a demeaning enrollment process were all cited as important barriers by eligibles. Zedlewski and Brauner (1999) find from survey results that those leaving the Food Stamp program cited higher income and administrative problems or hassles as the overwhelmingly dominant reasons for leaving the Food Stamp program. Stuber et al (2000) find from a survey of community health center users that confusion about rules is the most cited reason for not applying.

\section{Lessons from variation in take-up within programs}

\footnotetext{
${ }^{3}$ The theoretical literature on stigma includes Horan and Austin 1974, Rainwater 1982, Moffitt 1983, Besley and Coate 1992 and Yaniv 1997.
} 
Costs and benefits of program participation vary with individual characteristics, such as income and taste. This variation in the value of the same program characteristic across individuals suggests that it may be possible to draw inferences about program features that affect take-up through comparisons of take-up of one program across people with different characteristics. For example, the cost of spending time at administrative offices will vary from person to person. If time spent enrolling is an important barrier, then people with high time costs will have lower take-up rates than those with low time costs, all else held equal. We may be able to use some of the variation across individuals to draw inferences about the effects of program features.

There are two problems with this approach. First, inferring causality is difficult in cross-individual comparisons because the measured size of non-financial barriers may be influenced by individual benefits. For example, potential recipients may become informed about a program because they expect to receive high benefits. Second, it is difficult to relate individual characteristics to program features. Consider education, which is frequently used as a covariate in studies of take-up and frequently observed to be positively correlated with take-up. How should the effect of education on take-up be interpreted in order to illuminate the effects of program design? Education probably lowers the cost of gathering information. It also probably lowers the cost of filling out forms; predicts future income; and is correlated with asset levels, which are imperfectly measured in the data set. Thus, the observation that education is a significant predictor of take-up does not provide clear answers to which non-price features influence take-up and what the sizes of those effects are. 
Because of these problems, the best way to learn the causal impact of a program or program characteristics is an experiment with random assignment to treatment (e.g., program or program feature) and control groups. Although not common, one study actually performed such an experiment to examine the impact of information on take-up of food stamps. Daponte, Sanders and Taylor (1998) sampled low income people eligible on the basis of income and family size. Half were randomly assigned to be fully screened for eligibility and informed about the program and the other half were randomly assigned to be controls.

In the world of policy and evaluation, the next best thing to a randomized experiment for determining the causal effects of program design is natural exogenous variation over time or across groups. Three studies used this method. Madrian and Shea (2000) examined a change in the way one company administered its 401(k) plan. Prior to the policy change, employees had to actively elect to be in the program, filling out forms and making allocation decisions. Following the policy change, employees had to actively decline to participate in the $401(\mathrm{k})$ plan. If employees failed to decide, they received the default payroll deduction of 3\% and the default allocation. Garrett and Glied (2000) compare SSI take-up before and after a Supreme Court ruling affecting eligibility. Anderson and Meyer (1997) use longitudinal data to show how unemployment insurance take-up falls after UI benefits became subject to income tax.

A related approach is to use variation over time in take-up and its correlation with variation in other covariates to elucidate influences on take-up. Blank and Card (1991) examined the correlation between state-level take-up of unemployment insurance with the generosity of those benefits and the unionization rate (thought to be a proxy for 
information). Moffitt (1987) decomposed variation over time in state-level AFDC takeup rates into variation explained by benefit generosity and demographics and interpreted the residual as due to cultural factors.

A much large number of studies (including McGarry1996, Scholz 1994, Blundell et al. 1998, Blank and Ruggles 1996, Moffitt 1983), have examined the correlation of individuals' characteristics with their decision to participate in a particular program. Stuber et al (2000) combined a qualitative survey of community center users about their perceived problems of Medicaid with a cross-sectional analysis of the correlation between take-up and reasons given. As noted, identification of the effects of program characteristics from these studies is problematic. Nonetheless, it is possible to use the very extensive evidence on the correlates of observable individual characteristics and take-up to shed some light on the impact of program characteristics on take-up.

Variation in take-up rates across individual characteristics may be a function of how eligibility is measured. Studies typically find both false positives (people who collect benefits but appear ineligible) and false negatives (people who do not collect benefits but appear eligible). Agencies evaluating eligibility make mistakes. More importantly, studies are based on surveys that allow only an imperfect assessment of individual eligibility (Duclos, 1995; Hu, 1998). For example, many surveys do not collect information on assets, but many programs have asset limits on participation. Studies that compare take-up both with and without incorporating asset information find large differences in estimated take-up. In one study examining take-up of SSI by the elderly, the measured take-up rate for some groups increased by $60 \%$ after asset limits were included in the eligibility determination (Hu, 1998). Daponte, Sanders and Taylor 
(1998) found that after performing a more accurate eligibility screening test on their sample (including assets and deductions), only about half of those families that initially seemed eligible for food stamps were, in fact, eligible. These results suggest that take-up rates in programs with complex eligibility criteria may not be nearly as low as the rates calculated by researchers using survey data.

Table 2 describes the empirical evidence on the impact of various non-price influences on take-up. The table is organized by qualitative feature, such as informational barriers, stigma, and so on. As noted above, some individual characteristics may proxy for more than one, or uncertain, features. In these cases, we have used our own judgment about what features an individual characteristic proxies for and in some cases, used the same variable as possible evidence for more than one characteristic.

Program Benefits: $\quad$ Many experimental and non-experimental studies find that the size of potential benefits affects participation. The size of the financial gain should be measured over the period of participation. For example, Blank and Ruggles (1996) found, using longitudinal data, that women who ended up with shorter spells of unemployment were much less likely to sign up when they initially became eligible. Studies consistently find that the larger the benefits, the more likely potential recipients are to overcome other barriers and sign up for a program. Daponte, Sanders, and Taylor, for example, found that potential recipients were more likely to be informed about food stamps benefits the larger the size of the benefits for which they were eligible.

The importance of benefit size is also apparent in the many studies that look at enrollment in linked programs (not shown in Table). For example, take-up of food 
stamps is greater when receipt is automatic upon enrollment in the (more valuable) AFDC program than when eligible people must apply for food stamps separately (Zedlewski and Brauner, 1999). Take-up of Medicaid fell when the program became delinked from welfare during welfare reform (Ku and Garrett, 2000; Ellwood and Irvin, 2000). Take-up of welfare, which automatically provides people with Medicaid, is, in turn, greater among people who expect high medical costs than among healthier applicants (Blank, 1989; Moffitt and Wolfe, 1992). 
Inconvenience: $\quad$ Several studies use proxies, such as having a car or filing a related form, to assess the effects of inconvenience on participation. In general, the effects of these variables are statistically insignificant. Their magnitudes, however, may be nonnegligible. One study of welfare benefits in Britain estimated that the aggregate magnitude of inconvenience costs could be as much as $20 \%$ of the total benefit for the average eligible (Duclos 1995). Stuber et al (2000) found that those who perceived the applications as long and complicated were 1.8 times less likely to take-up Medicaid and those who felt that the application hours were inconvenient were 1.7 times less likely.

By contrast, however, automatic enrollment has an enormous effect on take-up. In the Madrian and Shea (2000) study of a company's 401(k) plan policy change, moving from voluntary to automatic enrollment resulted in an increase in the participation rate from $37 \%$ to $86 \%$ among employees with less than a year of tenure. The value of automatic enrollment is also clear in the studies of newly-delinked benefits. When enrollment into Medicaid and Food Stamps was an automatic corollary of welfare recipiency, many more potential eligibles enrolled (Zedlewski and Brauner 1999; Ku and Garrett 2000; Ellwood and Irvin 2000). 
Cultural Attitudes and stigma: $\quad$ Studies use a range of proxies for cultural factors and stigma. The proxies are hard to interpret and the results are generally weak. This is consistent with the interviews conducted by Daponte, Sanders, and Taylor, with food stamp eligibles that had been informed of their eligibility and yet had not signed up. Only one of the 16 households in this group replied with a reason describable as stigma; most said that it was not worth the trouble for the small benefit. Stuber et al found that all stigma measures were insignificantly related to take-up of Medicaid. ${ }^{4}$

Information: Cross-sectional analyses typically have weak proxies for the effects of information, such as educational attainment, and find weak results. Those that use survey information on whether and how people have learned about the program do find that information matters (see Huby and Whyley 1996 for an example). These studies are, however, vulnerable to the objection that knowledge about the program may be a function of expected benefits. Thus, the experimental study by Daponte, Sanders, and Taylor is particularly valuable here. They found that information does increase take-up of the food stamps benefit. $0 \%$ of those eligible but not already on Food stamps who were not informed of the benefit by researchers took up food stamps, while $36 \%$ of those who were informed took up the benefit and another $10 \%$ said they planned to. Stuber et al find that those confused about eligibility rules are 1.8 times less likely to take-up Medicaid. Neumann, Bernardin and Evans (1995) found from a survey of Medicare beneficiaries matched with Medicare data that while awareness of the Qualified Medicare Beneficary Program was correlated with take-up of that program, many of

\footnotetext{
${ }^{4}$ Stuber et al define stigma more broadly than we do and find that "having to answer unfair questions" and unequal treatment by doctors of Medicaid patients are statistically significant and significant in a policy
} 
those unaware of the program were actually enrolled. Presumably, providers looking to avoid bad debt for beneficiaries' share are an important impetus behind take-up.

\section{Lessons from variation in take-up across programs}

As Table 1 suggests, there is very large variation in take-up rates across programs. This variation can also help inform our understanding of what drives take-up, although it is sometimes difficult to attribute cross-program take-up variation to specific features. For example, some allege that it is so hard to get on Medicaid because politicians wish to keep the number of enrolled down. If such wishes have their origin in the sense that Medicaid is "bad" and if the same sense of "badness" drives low take-up through stigma, then we would falsely attribute the low take-up to high logistical barriers to Medicaid enrollment. A second difficulty comes from the qualitative nature of the some of the program design features and a lack of clear ability to measure and describe those features.

Looking across table 1 , one very striking pattern emerges. Those programs for which no "extra action" is required: Medicare part A, Medicare part B and employersponsored insurance have the highest take-up rates. Medicare does not require any signup. People are automatically enrolled when they reach 65 . They receive a form that they must return if they wish to decline part B coverage. Thus, it requires positive action to avoid part B, while everyone eligible receives part A no matter what. ESI is done using payroll deduction and is generally performed automatically by the workplace benefits office. The earned income tax credit (EITC), which does not require extra paperwork for those already filing income tax returns, also has a very high take-up rate. In contrast, other programs, which do require extra action have much lower take-up rates. 
Second, programs that have complex eligibility criteria, such as asset tests, appear to have more variable take-up across studies than simpler programs. Whether survey or administrative data are used appears to affect measured take-up rates. Survey data may not be sufficiently rich to capture all eligibility features, leading to underestimates of true take-up.

\section{Conclusions}

The low take-up of many programs is surprising to many economists, seeming to represent "money on the table." Without understanding the causes of low take-up, it is hard to design better programs. With essentially no information on the quantitative effects of non-financial program characteristics, it is virtually impossible to make quantitative predictions about the effects of different program features. More research is greatly needed - especially research that can be used to draw measurable causal inferences about how such features as administrative complexity, renewal rules, and organizational structure affect participation. To draw causal inferences we need randomized experiments or cross-sectional and longitudinal econometric work that exploits exogenous variation (natural experiments) across time, geographic area or other

administrative entity. In order for such evidence to be useful for evaluating non-financial aspects of programs, these studies must have carefully developed measures of the more qualitative program characteristics. The development of such measures, combined with natural and randomized experiments, would greatly increase our knowledge of how to design programs with higher take-up rates. 
Nonetheless, looking across individuals and programs, several conclusions can be drawn. First, the size of a benefit is the most consistently important predictor of participation. Second, information can help, but how much information people absorb may be related to potential benefits. Third, although the evidence is limited, stigma does not seem to be important. Fourth, mismeasurement of eligibility may be an important contributor to poor take-up numbers. Finally and most strikingly, reducing individual administrative barriers seems to have little effect but moving from voluntary to automatic coverage is extremely effective.

What does this mean for health insurance? The evidence cited shows that the value of the benefit is a great predictor of the likelihood of take-up. It may well be that potential recipients do not value health insurance as strongly as policy analysts do-a possibility worth exploring in depth. Since Medicaid is effectively available retroactively, health insurance is certainly not as critical for the segment of the population eligible for Medicaid.

Overall, there is little evidence suggesting that most non-financial program features really matter. The one exception is automatic enrollment: looking broadly across many programs, it seems clear that automatic enrollment is the best way to increase takeup. Clearly, a universal entitlement for some form of health insurance, even a stripped down version, coupled with automatic enrollment would solve the problem of the uninsured. Whether some form of automatic enrollment short of universal entitlement is practical is a question worth exploring. 


\section{Bibliography}

Anderson, Patricia M. and Bruce D. Meyer "Unemployment Insurance and the After-Tax Value of Benefits" Quarterly Journal of Economics August 1997.

Besley, Timothy and Stephen Coate, "Understanding Welfare Stigma: Taxpayer Resentment and Statistical Discrimination” Journal of Public Economics 48(2): 165-83, 1992.

Blank, Rebecca M. and David E. Card "Recent Trends in Insured and Uninsured Unemployment: Is There an Explanation?” Quarterly Journal of Economics 1064(4): 1157-89, 1991.

Blank, Rebecca and Patricia Ruggles. "When Do Women Use Aid to Families with Dependent Children and Food Stamps? The Dynamics of Eligibility vs. Participation" Journal of Human Resources 31(1): 57-89, 1996.

Blank, Rebecca. "The Effect of Medical Need and Medicaid on AFDC Participation" Journal of Human Resources 24(1): 54-87, 1989.

Blundell, Richard, Vanessa Fry and Ian Walker, "Modelling the Take-up of MeansTested Benefits: The Case of Housing Benefits in the United Kingdom" The Economic Journal 98(390) Supplement 1998.

Castner, Laura and Scott Cody, "Trends in Food Stamp Participation Rates: Focus on" November 1999, USDA Report.

Cooper, Philip, and Barbara Steinberg Schone. "More Offers, Fewer Takers for Employment-Based Health Insurance: 1987 and 1996” Health Affairs 16(6): 142-149, November/December 1997.

Craig, Peter. "Costs and Benefits: A Review of Research on Take-up of Income-Related Benefits” Journal of Social Policy 20(4): 537-565,1991.

Currie, Janet and Jonathan Gruber. "Health Insurance Eligibility, Utilization of Medical Care and Child Health" Quarterly Journal of Economics III(2): 431-466, May 1996.

Daponte, Beth Osborne, Seth Sanders, and Lowell Taylor, "Why Do Low-Income Households Not Use Food Stamps?" Evidence from an Experiment, Journal of Human Resources XXXIV(3): 612, 1998.

Dion, M. Robin and LaDonna Pavetti, "Access to and Participation in Medicaid and the Food Stamp Program: A Review of the Recent Literature", Mathematica Policy Research report, 2000.

Duclos, Jean-Yves "Modelling the take-up of state support" Journal of Public Economics 58: 391-415, 1995. 
Ellwood, Marilynn and Carol Irvin, "Welfare Leavers and Medicaid Dynamics: Five States in 1995" Assistant Secretary for Policy and Evaluation's office, Department of Health and Human Services Report, April 2000.

Garrett, Bowen and Sherry Glied, "Does State AFDC Generosity Affect Child SSI

Participation?” Journal of Policy Analysis and Management 19(2): 275-295, 2000.

General Accounting Office "Low Income Medicare Beneficiaries: Further Outreach and Administrative Simplification Could Increase Enrollment” GAO Report HEHS-99-61, April 1999.

Horan, Patrick M. and Austin, Patricia Lee, "The Social Bases of Welfare Stigma" Social Problems.

$\mathrm{Hu}$, Wei-Yin "Elderly Immigrants on Welfare" Journal of Human Resources XXXIII(3): 711-741, 1998.

Huby, Meg and Claire Whyley "Take-up and the Social Fund" Journal of Social Policy 25(1): 1-18, 1996.

Koning, Ruud H. and Geert Ridder "Rent Assistance and Housing Demand" Journal of Public Economics 66:1-31, 1997.

$\mathrm{Ku}$, Leighton and Bowen Garrett, "How Welfare Reform and Economic Factors Affected Medicaid Participation: 1984-96" Urban Institute Working Paper 00-01, 2000.

Long, Stephen H. and M. Susan Marquis. "Gaps in Employer Coverage: Lack of Supply Or Lack of Demand?” Health Affairs 12(?): 282, Supplement 1993.

Madrian, Brigitte C. and Dennis F. Shea "The Power of Suggestion: Inertia in 401(k) Participation and Savings Behavior” NBER working paper 7682, 2000.

McGarry, Kathleen. "Factors Determining Participation of the Elderly in Supplemental Security Income" Journal of Human Resources 31(2), 1996.

Moffitt, Robert “An Economic Model of Welfare Stigma” American Economics Review 73(5): 1023-1035, 1983.

Moffitt, Robert "Historical Growth in participation in Aid to Families with Dependent Children: Was there a structural shift?” Journal of Post Keynesian Economics IX (3): 347, 1987.

Moffitt, Robert and Wolfe, Barbara "The Effect of the Medicaid Program on Welfare Participation and Labor Supply" Review of Economics and Statistics 615-626, 1992.

Neumann, Peter J., Mimi D. Bernardin, and William N. Evans "Participation in the qualified Medicare Beneficiary Program” Health Care Financing Review 17: 169-78, 1995. 
Perry, Michael J., Evan Stark, and R. Burgiaga Valdez, "Barriers to Medi-Cal Enrollment and Ideas for Improving Enrollment: Findings from Eight Focus Groups in California with Parents of Potentially Eligible Children", Kaiser Family Foundation publication \#1436, September 1998.

Scholz, John Karl. "The Earned Income Tax Credit: Participation, Compliance and Antipoverty Effectiveness" National Tax Journal 47(1): 63-85, 1994.

Stuber, Jennifer P., Kathleen A, Maloy, Sara Rosenbaum, and Karen C. Jones. "Beyond Stigma: What Barriers Actually Affect the Decisions of Low-Income Families to Enroll in Medicaid?" Center for Health Services Research and Policy George Washington University working paper, July 2000.

Rainwater, Lee, "Stigma in Income-Tested Programs" in Income-Tested Transfer Programs: The Case For and Against edited by Irwin Garfinkel, New York: Academic Press, 1982.

Selden, Thomas, Jessica Banthin and Joel Cohen, "Medicaid's Problem Children: Eligible but Not Enrolled" Health Affairs 17(3): 192-200, 1998.

Storer, Paul and Marc A. Van Audenrode "Unemployment Insurance Take-up Rates in Canada: Facts, Determinants and Implications" Canadian Journal of Economics XXVIIII(4a): 822-35, 1995.

Thorpe, Kenneth and Curtis Florence. "Why are Workers Uninsured? EmployerSponsored Health Insurance in 1997” Health Affairs March/April 1999

Warlick, Jennifer L. "Participation of the Aged in SSI" Journal of Human Resources 17(2): 236-60, Spring1982.

Yaniv, Gideon "Welfare Fraud and Welfare Stigma” Journal of Economic Psychology 18:435-451, 1997.

Zedlewski, Sheila and Sarah Brauner, "Declines in Food Stamp and Welfare Participation: Is There a Connection?” Urban Institute Working Paper 99-13, 1999. 
Table 1:

\begin{tabular}{ll}
\hline Program & Take-up Rate \\
\hline Medicare Part A & $99 \%$ \\
Medicare Part B $^{5}$ & $95.5 \%$ \\
Employer Sponsored Insurance $^{6}$ & $80 \%-87 \%$ \\
Earned Income Tax Credit $^{7}$ & $80-86 \%$ \\
Food Stamps $^{8}$ & $54-71 \%$ \\
Unemployment Insurance $^{9}$ & $65 \%-83 \%$ \\
Rental Assistance $^{10}$ & $64 \%$ \\
SSI (elderly) $^{11}$ & $50 \%-56 \%$ \\
Medicaid (eligible uninsured children) $^{12}$ & $50-70 \%$ \\
AFDC (female heads) $^{13}$ & $45 \%-70 \%$ \\
QMB and SLMB (Medicare Assistance) $^{14}$ & $43 \%$ \\
\hline
\end{tabular}

Note: Take-up rates are for a variety of different years (1975-1996) and in some cases different countries (rental assistance in the Netherlands, UI in Canada as well as the US). Some program figures include multiple studies.

\footnotetext{
${ }^{5}$ Authors' calculations from Health Care Financing Administration Data. The number of people who have part A but not part B coverage divided by the number who have part A coverage.

${ }^{6}$ Sources: Long and Marquis, Thorpe and Florence, Cooper and Schone. Results from CPS and MEPS, 1987-97. Note that for ESI, about $10 \%$ of those who decline ESI have coverage from another source.

${ }^{7}$ Source: Scholz, using 1990 SIPP Data.

${ }^{8}$ Sources: Castner and Cody 1999, Blank and Ruggles. Results from SIPP, CPS and administrative records.

${ }^{9}$ Sources: Blank and Card, Storer and Van Audenrode.

${ }^{10}$ Source: Koning and Ridder.

${ }^{11}$ Sources: Warlick, McGarry. CPS and SIPP.

${ }^{12}$ Source: Currie and Gruber 1996a.

${ }^{13}$ Sources: Moffitt 1987, Blank and Ruggles.
} 

Table 2: Evidence of Non-price effects on take-up by Qualitative Feature

\begin{tabular}{|c|c|c|c|}
\hline Program & Paper & Means of Estimating Effect & $\begin{array}{l}\text { Quality of Estimates/ } \\
\text { Statistical and Economic Significance }\end{array}$ \\
\hline \multicolumn{4}{|c|}{ Financial Value of Benefit } \\
\hline SSI & Garrett and Glied & $\begin{array}{l}\text { State level panel data; difference in difference estimation; supreme court } \\
\text { decision changed rules in some states; Size of financial incentive effect to } \\
\text { switch from AFDC to SSI }\end{array}$ & $\begin{array}{l}\text { Significant: The greater the difference in } \\
\text { benefits, the more likely a family will } \\
\text { switch from AFDC to SSI }\end{array}$ \\
\hline $\begin{array}{l}\text { Food Stamps and } \\
\text { AFDC }\end{array}$ & $\begin{array}{l}\text { Blank and } \\
\text { Ruggles }\end{array}$ & $\begin{array}{l}\text { Longitudinal Data comparing eligibility for Food stamps and AFDC with } \\
\text { take-up }\end{array}$ & $\begin{array}{l}\text { Length of eligibility or "need" important } \\
\text { determinant of take-up }\end{array}$ \\
\hline UI & Blank and Card & $\begin{array}{l}\text { State level panel regressions of take-up on state-year characteristics } \\
\text { Replacement rate }\end{array}$ & $\begin{array}{l}\text { State-level replacement rate is } \\
\text { insignificant }\end{array}$ \\
\hline $\begin{array}{l}\text { Housing Benefits } \\
\text { in UK }\end{array}$ & Blundell et al & $\begin{array}{l}\text { Cross-sectional probit estimation of the effect of income and the size of } \\
\text { benefit on take-up }\end{array}$ & $\begin{array}{l}\text { Significant effect of both income and size } \\
\text { of benefit }\end{array}$ \\
\hline UI & $\begin{array}{l}\text { Anderson and } \\
\text { Meyer }\end{array}$ & Longitudinal estimation of change in tax treatment of UI benefits & $\begin{array}{l}\text { Statistically Significant } \\
\text { "A tax increase that lowered after-tax } \\
\text { benefits by } 10 \text { percent would lower take- } \\
\text { up by } 0.5-1 \text { percentage points." }\end{array}$ \\
\hline AFDC & Moffitt 1983 & Cross-sectional structural model estimation & $\begin{array}{l}\text { Statistically significant } \\
\text { Participation rose by } 11 \text { percentage points } \\
\text { for a substantial benefit increase policy } \\
\text { proposal }\end{array}$ \\
\hline EITC & Scholz & $\begin{array}{l}\text { Cross Sectional probits of non-participation; } \\
\text { Size of potential EITC }\end{array}$ & Insignificant (borderline) \\
\hline
\end{tabular}




\begin{tabular}{|c|c|c|c|}
\hline \multicolumn{4}{|c|}{ Inconvenience } \\
\hline SSI & McGarry & $\begin{array}{l}\text { Cross Sectional variation in take-up for invariant SSI program; } \\
\text { Having a car, living in an MSA, good health proxy for convenience }\end{array}$ & $\begin{array}{l}\text { Car owner: insignificant } \\
\text { same MSA: marginally significant } \\
\text { Poor health: significant }\end{array}$ \\
\hline EITC & Scholz & $\begin{array}{l}\text { Cross Sectional probits of non-participation; } \\
\text { Existence of state income tax }\end{array}$ & $\begin{array}{l}\text { significant } \\
\text { No state income tax system makes people } \\
7.6 \% \text { less likely to take up EITC }\end{array}$ \\
\hline UI & Blank and Card & $\begin{array}{l}\text { State level panel regressions of take-up on state-year characteristics } \\
\text { Unionization rate proxy for lack of informational barriers }\end{array}$ & $\begin{array}{l}\text { Significant: poor proxy for informational } \\
\text { barriers }\end{array}$ \\
\hline Private Pensions & Madrian and Shea & Natural experiment of firm changing to default participation & $\begin{array}{l}\text { Dramatic Effect } \\
\text { BUT it may be due more to other } \\
\text { psychological factors than the actual } \\
\text { convenience }\end{array}$ \\
\hline Medicaid & Stuber et al & $\begin{array}{l}\text { Survey of non-generalizable sample of community health center user } \\
\text { Cross-sectional (logistic regression) analysis of correlation between take- } \\
\text { up and perceived problems with Medicaid }\end{array}$ & $\begin{array}{l}\text { Perceiving forms as long and complicated } \\
\text { implies } 1.8 \text { times less likely to take-up } \\
\text { Medicaid. } \\
\text { Perceiving hours as inconvenient implies } \\
1.7 \text { times as less likely to take-up }\end{array}$ \\
\hline
\end{tabular}




\begin{tabular}{|c|c|c|c|}
\hline \multicolumn{4}{|c|}{ Stigma and Cultural Attitudes } \\
\hline UI & Blank and Card & Democrats' share of house delegation & \\
\hline SSI & McGarry & $\begin{array}{l}\text { Cross Sectional variation in take-up for invariant SSI program; } \\
\text { Stigma is proxied by the lack of use of other welfare programs } \\
\text { Stigma is proxied by not being in South }\end{array}$ & $\begin{array}{l}\text { Highly statistically significant; } \\
\text { South not significant }\end{array}$ \\
\hline AFDC & Moffit 1987 & $\begin{array}{l}\text { Repeated cross sectional estimates of the effect of demographics and } \\
\text { generosity on take-up; used to decompose change over time into changes } \\
\text { explained by demographics and program generosity and "unexplained } \\
\text { variation"; unexplained variation assumed to reflect cultural attitudes }\end{array}$ & $\begin{array}{l}\text { Economic variables' significance declines } \\
\text { over time and participation rises for } \\
\text { unexplained reasons assumed to reflect } \\
\text { changes in cultural attitudes. }\end{array}$ \\
\hline Food Stamps & Daponte et al & Questioning those who are eligible but not receiving & $\begin{array}{l}\text { Stigma is small-of little policy } \\
\text { significance }\end{array}$ \\
\hline AFDC & Horan and Austin & $\begin{array}{l}\text { Tabulations of survey of } 50 \text { Southern black AFDC recipients } \\
\text { Education and age assumed to be proxies for stigma } \\
\text { Knowledge of welfare rights organization proxies for lack of stigma }\end{array}$ & $\begin{array}{l}\text { Not statistically significant (small sample } \\
\text { size) } \\
\text { Poor proxies for stigma }\end{array}$ \\
\hline AFDC & Moffitt 1983 & $\begin{array}{l}\text { Cross-sectional structural model estimation } \\
\text { Effect of unobservable stigma varies by age, education, family size and } \\
\text { unemployment }\end{array}$ & $\begin{array}{l}\text { Statistically significant effects but the } \\
\text { interpretation in terms of stigma's effect } \\
\text { is difficult }\end{array}$ \\
\hline Medicaid & Stuber et al & $\begin{array}{l}\text { Survey of non-generalizable sample of community health center user } \\
\text { Cross-sectional (logistic regression) analysis of correlation between take- } \\
\text { up and perceived problems with Medicaid }\end{array}$ & $\begin{array}{l}\text { Stigma measures insignificantly related to } \\
\text { take-up }\end{array}$ \\
\hline
\end{tabular}




\begin{tabular}{|c|c|c|c|}
\hline \multicolumn{4}{|c|}{ Informational Barriers } \\
\hline Food Stamps & Daponte et al. & Randomized treatment and control (provision of information) & $\begin{array}{l}\text { Statistically significant; Magnitude } \\
\text { modest; Information appears } \\
\text { endogenous - those with greatest } \\
\text { potential benefit unlikely to be } \\
\text { uninformed }\end{array}$ \\
\hline EITC & Scholz & Income, education, other welfare programs, occupation & Poor proxies for information; \\
\hline $\begin{array}{l}\text { Qualified } \\
\text { Medicare } \\
\text { Beneficiary } \\
\text { Program (QMB) } \\
\end{array}$ & Neumann et al. & $\begin{array}{l}\text { Survey of Medicare Beneficiaries merged with Medicare and QMB and } \\
\text { Medicare Data; Beneficiaries asked about awareness of program }\end{array}$ & $\begin{array}{l}60 \% \text { of those eligible and with knowledge } \\
\text { of program take-up } \\
\text { BUT } 40 \% \text { of those eligible and unaware } \\
\text { of program also take-up!! }\end{array}$ \\
\hline Food Stamps & Daponte et al. & Randomized Experiment & $\begin{array}{l}\text { Among those eligible but not yet } \\
\text { participating, } 36 \% \text { of those informed of } \\
\text { eligibility took up vs. } 0 \% \text { of those not } \\
\text { informed. }\end{array}$ \\
\hline Medicaid & Stuber et al & $\begin{array}{l}\text { Survey of non-generalizable sample of community health center user } \\
\text { Cross-sectional (logistic regression) analysis of correlation between take- } \\
\text { up and perceived problems with Medicaid }\end{array}$ & $\begin{array}{l}\text { Confusion about Medicaid eligibility } \\
\text { rules implies } 1.8 \text { times less likely to take- } \\
\text { up }\end{array}$ \\
\hline
\end{tabular}


